\title{
Recovery of adrenocortical function following treatment of tuberculous Addison's disease
}

\author{
Juliet Penrice and S.S. Nussey
}

Department of Medicine, St George's Hospital Medical School, Cranmer Terrace, London SW17 ORE, UK ڤ

\begin{abstract}
Summary: We report two cases of Addison's disease occurring in association with proven Mycobacterium tuberculosis infection. Both were treated with modern chemotherapeutic agents and were shown to have developed normal adrenal cortical function after several years. We suggest that adrenal function should be tested after modern anti-tuberculous therapy of this disease.
\end{abstract}

\section{Introduction}

Tuberculous Addison's disease is now rare. Despite the fact that the adrenal cortex has considerable capacity for regeneration, this disease is generally regarded as incurable with substitution therapy being required for the rest of the patient's life. We report here two cases of tuberculous Addison's disease who subsequently had normal Synacthen tests, and from whom steroid therapy has successfully been withdrawn.

\section{Case reports}

\section{Case 1}

A 57 year old Caucasian woman with a past history of tuberculous peritonitis at the age of 20 years was admitted disorientated, unable to walk and febrile. On examination, she was conscious but drowsy with a temperature of $39^{\circ} \mathrm{C}$ and a blood pressure of $100 / 60 \mathrm{mmHg}$. She had marked neck stiffness. On investigation, the plasma sodium was $126 \mathrm{mmol} / \mathrm{l}$, potassium $4.6 \mathrm{mmol} / \mathrm{l}$, bicarbonate $25 \mathrm{mmol} / \mathrm{l}$ and urea $15.8 \mathrm{mmol} / \mathrm{l}$. The cerebrospinal fluid (CSF) pressure was $120 \mathrm{~mm}$, protein $2.5 \mathrm{~g} / \mathrm{l}$, glucose $1.1 \mathrm{mmol} / \mathrm{l}$ (with a plasma glucose of $5.6 \mathrm{mmol} / \mathrm{l}$ ), cells: 340 lymphocytes $/ \mathrm{mm}^{3}$. No acid-fast bacilli were seen on microscopy but a presumptive diagnosis of tuberculous meningitis was made (and later confirmed by culture of Mycobacterium tuberculosis from the CSF).

Correspondence: S.S. Nussey, M.A., D.Phil, M.R.C.P. Accepted: 8 August 1991
She was treated with streptomycin, rifampicin, 은 isoniazid and pyridoxine. Four days later she was $\vec{\longrightarrow}$ afebrile with a CSF protein of $1.5 \mathrm{~g} / 1$ and only 30 lymphocytes $/ \mathrm{mm}^{3}$. Neurologically, however, she $\stackrel{\widehat{S}}{\mathcal{S}}$ had deteriorated and was unconscious responding only to pain. Her plasma sodium had dropped 8 $117 \mathrm{mmol} / \mathrm{l}$; she was treated with intravenow ? saline and both glucocorticoids and mineraloco 0 s ticoids with rapid improvement. After discharge the steroids were tailed off.

During the 6 months after stopping steroids she became increasingly pigmented; this included her $\stackrel{\mathbb{Q}}{\varrho}$ buccal mucosa. She was otherwise well with no $\vec{\nexists}$ postural fall in blood pressure and normal electro- $\frac{3}{3}$ lytes. A Synacthen test ( $1 \mathrm{mg}$ depot $\mathrm{ACTH}_{1-24}$ i.m.) confirmed Addison's disease with cortisol levels of $313 \mathrm{nmol} / 1$ at time zero, $335 \mathrm{nmol} / 1$ at $1 \mathrm{~h}$ and $263 \mathrm{nmol} / 1$ at $5 \mathrm{~h}$. Calcification of the adrenal 3 . glands was present on abdominal X-ray. Treat- $\dot{0}$ ment was commenced with $37.5 \mathrm{mg}$ cortisone $\underline{3}$. acetate per day.

Her pigmentation resolved. Two years later she was noted to have an elevated blood pressure of 9 $160 / 90 \mathrm{mmHg}$. Over the next 15 months increasing $>$ hypertension necessitated a gradual reduction in steroid dose. Finally steroids were completely withdrawn; one month later a further Synacthen or test (1 mg depot $\mathrm{ACTH}_{1-24} \mathrm{im}$ ) was performed. $N$ The cortisol level was $428 \mathrm{nmol} / 1$ at time zero, $\underset{\omega}{N}$ $655 \mathrm{nmol} / 1$ at $30 \mathrm{~min}, 1103 \mathrm{nmol} / \mathrm{l}$ at $4 \mathrm{~h}$ and over 0 $1320 \mathrm{nmol} / \mathrm{l}$ at $12 \mathrm{~h}$. The patient has now been off steroids for 11 years and remains completely well.

Case 2

A 33 year old Afro-Caribbean woman presented a $\stackrel{\overparen{D}}{\circ}$ fortnight after the delivery of her second child, $\mathbb{\otimes}$ 
following which she had felt generally unwell and had lost weight. She was admitted with a 3 day history of sore throat, anorexia and progressively abnormal behaviour. She finally lapsed into coma and was fitting on arrival in casualty. Hypoglycaemia was confirmed with a venous plasma glucose of $0.6 \mathrm{mmol} / \mathrm{l}$. (A corresponding plasma insulin was $1.7 \mu \mathrm{U} / \mathrm{ml}$.) In retrospect she admitted to feeling odd if she did not eat and to using six spoonfuls of sugar in each cup of tea. She had a fever of $39.8^{\circ} \mathrm{C}$ and a blood pressure of $100 /$ $60 \mathrm{mmHg}$. Her plasma sodium was $130 \mathrm{mmol} / 1$, potassium $3.0 \mathrm{mmol} / \mathrm{l}$, bicarbonate $16 \mathrm{mmol} / \mathrm{l}$ and urea $5.6 \mathrm{mmol} / \mathrm{l}$. She was found to be septicaemic with a significant growth of a Streptococcus sp. on blood culture. This responded to penicillin. Her chest X-ray was normal. An insulinoma was suspected, but after detailed investigation, no supportive evidence was found.

Four months later she was readmitted with a 3 week history of tiredness, weight loss, vomiting and dizziness on standing. She had noticed progressive darkening of her skin and had a cough productive of white sputum. Examination revealed pigmentation of the gums, fauces and buccal mucosa with darkening of the palmar creases. Her blood pressure was $100 / 70 \mathrm{mmHg}$ supine and $80 / 60 \mathrm{mmHg}$ erect. Bronchial breathing was audible over the right apex.

On investigation her blood urea and electrolytes were normal. A random plasma glucose was $3.8 \mathrm{mmol} / 1$. Her chest X-ray showed collapse and consolidation of the right upper lobe and a narrow cardiac silhouette. A Synacthen test $(250 \mu \mathrm{g}$ $\mathrm{ACTH}_{1-24}$ i.m.) demonstrated plasma cortisols of $77 \mathrm{nmol} / 1$ at time zero (9 a.m.), $83 \mathrm{nmol} / 1$ at $30 \mathrm{~min}$ and $83 \mathrm{nmol} / 1$ at $60 \mathrm{~min}$. A tuberculin test $(1: 10,000)$ was positive, bronchial biopsy revealed granulomata and Mycobacterium tuberculosis was grown from the sputum. Adrenal and other organ specific autoantibodies were negative.

She was started on cortisone acetate $12.5 \mathrm{mg}$ twice a day and fludrocortisone $50 \mu \mathrm{g}$ daily with marked symptomatic improvement. She also received ethambutol, rifampicin, isoniazid and pyridoxine.

\section{References}

1. Guttman, P.H. Addison's disease: a statistical analysis of 566 cases and a study of pathology. Arch Pathol 1930, 10: 742-785, 895-935.

2. Hornsby, P.J. The regulation of adrenocortical function by control of growth and structure. In: Anderson, D.C. \& Winter, J.S.D. (eds) Adrenal Cortex. Butterworths, London, pp. 1-31.

3. Osa, S.R., Peterson, R.E. \& Roberts, R.B. Recovery of adrenal reserve following treatment of disseminated South American blastomycosis. Am J Med 1981, 71: 298-301.
During treatment with rifampicin, there was no need to increase the cortisone dose, and fludrocortisone was stopped after 2 years because of oedema. When reviewed 15 years later, it was noted that she suffered no ill-effect when forgetting to take her cortisone. After withdrawing cortisone for two weeks, a Synacthen test $\left(250 \mu \mathrm{g} \mathrm{ACTH}_{1-24}\right.$ i.m. $)$ produced plasma cortisols of $322 \mathrm{nmol} / \mathrm{l}$ at time zero, $558 \mathrm{nmol} / 1$ at $30 \mathrm{~min}$ and $638 \mathrm{nmol} / \mathrm{l}$ at $60 \mathrm{~min}$. All steroid therapy was therefore stopped with no ill-effect.

\section{Discussion}

Tuberculous Addison's disease is now rare. It is a diagnosis which, except at post mortem is nearly always made in the absence of histological confirmation. A tuberculous aetiology of Addison's disease is strongly suggested in both these cases by the temporal relationship to proven tuberculosis at other sites, the absence of adrenal autoantibodies and the presence, in one patient, of adrenal calcification.

The pathological features of the disease include destruction of the cortex and medulla of both adrenal glands with the formation of caseating granulomata; islands of normal cortical tissue may however remain. ${ }^{1}$ The adrenal cortex has considerable capacity to regenerate with marked hyperplasia and hypertrophy of cortical cells. ${ }^{2}$

Recovery of adrenal reserve in Addison's disease due to disseminated South American blastomycosis following treatment with amphotericin B has been documented. ${ }^{3}$ However, while modern chemotherapy is highly successful in the treatment of tuberculosis, recovery of adrenal function in tuberculous Addison's disease is not a wellrecognized phenomenon; a literature search revealed only two previous reports documenting cure of this disease. ${ }^{4,5}$ We suggest, however, that adrenal function should be tested after modern antituberculous chemotherapy of this disease.

4. Annear, T.D. \& Baker, G.P. Tuberculous Addison's disease: a case apparently cured by chemotherapy. Lancet 1961, 11: 577-578.

5. Coleman, E.N. \& Arneil, G.C. Acute tuberculous adrenocortical failure with clinical recovery. Lancet 1962, 1: 886-888. 